that the taxonomy of these forms was based (at least in this case) on phenotypic rather than genotypic characters.

The excursion in the afternoon, led by Dr. McKerrow and Dr. H. G. Reading, visited first an oxposure of the Great Oolite at Crawley Road Quarry, Witney, where members saw a Bradford Fossil Bed reef in the Forest Marble. The presence in this reef of remains of all animal groups except cephalopods suggests a shallow lagoon in which the water was too turbulent for cephalopods. 'The second quarry visited showed $a_{c}$ 'Corallian' reef at Shelling- ford Cross Roads Quarry, near Faringdon, where members saw patches of massive corals in early layers give way to mainly loosely-branching corals higher up, suggesting an increase in the depth of the water at this particular locality with time. The detrital Wheatley Limestone in this quarry was seon below the Coral Rag.

In the course of the symposium special thanks were expressed to Prof. J. W. S. Pringle for entertaining the meeting at Oxford.

D. V. AgER

D. NICHOLS

\title{
FOREST RESEARCH
}

$\mathrm{M}$ ANY factors influence the growth of forest trees, and these factors cover a particularly wide range when the practice of forestry is largely concerned with afforestation and the use of exotic trees. Thus it is easy to understand why forest research in Britain is so comprehensive. This is certainly shown by the numerous projects described in the annual report of the Forestry Commission for the year ending March 1962*.

Where so much dependence is placed on seed supply for ensuring the large planting programme, provenance and genetics are very important. Not only are vigorous trees wanted but also especial attention is being directed to those provenances which show resistance to frost. So that the forester may know where to obtain tree seed in Britain of the best of the existing varieties and cultivars, the Register of Seed Sources has been brought up to date and it now contains $\mathbf{5 3 5}$ classified seed sources totalling 8,833 acres. Associated with this has been the work of converting the best seed sources into seed stands and thus improving the genetic quality of seed collected in Britain.

Much attention is being directed to the study of soil moisture. Deep peat remains a problem with its poor drainage, the physical instability of the trees, the difficulties of timber extraction and not enough being known about the water and nutrient régimes of the trees. There is another drainage problem on heavy clay soils, but some hope is seen in improved types of mechanical drain diggers.

Exposure is a limiting factor to afforestation on many sites in Britain, and it is not easy of assessment. However, an inexpensive technique has been developed by using the rate of tatter of standard cotton flags set up for a period on the sites being studied. An account of this method is to be published soon. Wind damage is being examined from various aspects, and one project uses a wind tunnel to determine the relationship between wind velocity and the forces acting on a tree. Another project utilizes the 'tree-pulling' technique to test the effect of direction of pull on tree resistance. Both series of experiments should bring out useful information, but they do not seem to take into consideration that trees in a forest are often subjected to gusts and turbulence and not to a steady force of wind.

The annual report for the New Zealand Forest Service $\dagger$, covering the period January 1-December 31, 1962, shows an economic flavour. Emphasis is laid on the quality of the end-product so that utilization will be the most profitable possible. Hitherto, New Zealand's high-grade timber has largely come from its indigenous forests, but these resources are now approaching exhaustion. The tools at the disposal of the sylviculturist in order to obtain a better proportion of good-grade timber from the exotic forests are pruning and thinning and, therefore, present investigations are attempting to relate pruning and its effect on grade enhancement and the relationship between green crown depth and the density of the stand. However, the importance of protection forestry is not being for gotten. More watershed surveys have been carried out. and some reveal conditions which are rather disturbing. Active erosion and the resulting outpourings of detritus into streams may be largely due to red deer, goats and opossums destroying the protective vegetation cover. In some of the more accessible areas, hunters appear to exert sufficient control on the deer numbers and so the vegetation cover is in reasonable condition to give adequate protection against soil erosion.

C. J. TAYTOR

* Forestry Commission. Report on Forest Research for the year ended March, 1962. Pp. ix $+194+12$ plates. (London: H.M.S.O., 1963.) 13s. net.

$\dagger$ New Zealand Forest Service : Forest Research Institute. Report of the Forest Research Institute, Rotorua, for the period January 1 to December 31
1962. Pp. $86+9$ plates. (Wellington : Government Printers, 1963.)

\section{RETURN OF THE NENE TO HAWAII}

\begin{abstract}
GROM the beginning of the Wildfowl Trust's attempts to rear the Hawaiian geese, Branta sandvicensis, in 1950, it had been hoped that it would become possible to return the Hawaii geese reared at Slimbridge. The growth of the stock has been slow and some of the birds raised have been dispersed to other colloctions in Europe and North America in order to increase the chance of maintaining and developing flourishing stocks in captivity. By 1960, however, enough geese had been reared to allow the return of some of the nenes to Hawaii. It was not until the summer of 1962 that this somewhat complicated and expensive operation could actually be carried out*.

The Division of Fish and Game, Department of Land and Naturad Rasources of the State of Hawaii, proposed that the Slimbridge-reared geese should be used in an attempt

* The Wildfowl Trust. Fourteenth Annual Report, 1961-62. Edited by
Iugh Boyd. Illustrated by Peter Scott. Pp. 180+42 photographs, (Slim. Hugh Boyd. Illustrated by Peter Scott. Pp. $180+42$ photographs. (Slim-
bridge: The Wildfowl Trust, 1963.) 17s. 6 . net.
\end{abstract}

to re-establish the species on the Island of Maui, where it had been extinet for many years. A survey of the existing habitat on Maui in June 1960 showed that there were 9,000 acres of excellent nene habitat and a further 30,000 acres likely to be of some value. A release site was selected near Paliku within the Haleakala National Park. There were strong reasons for this choice: the area at the upper end of the Kampo Gap provides excellent nene habitat with food throughout the year; it is remote, ensuring a minimum of disturbance to the birds in the release pen; suitable accommodation exists for the people noeded to care for the birls.

In June 1962 thirty gease were despatched by air from Slimbridge to New York. They were taken to the U.S. Federal Quarantine Station at Clinton, New Jersey, where they were held for 21 days. They were thon sent on by air freight to Honolulu. There they were kept in the Zoo for three days to recover from the journey and were 